УДК 82.161.2+82.111

https://doi.org/10.31548/philolog2019.02.012

\title{
BIBLICAL INTERTEXTUALITY DEVICES IN AFRICAN AMERICAN RAP TEXTS (BASED ON THE KENDRICK LAMAR'S ALBUM “DAMN")
}

\author{
N. K. KRAVCHENKO, Dr. in Philology, Professor, \\ National university of life and environmental sciences of Ukraine
}

E-mail: nkravchenko@outlook.com ORCID: 0000-0001-9839-6629

\begin{abstract}
The research is concerned with the biblical intertextuality of the Kendrick Lamar's album "Damn" reflecting the rapper meta-modernist opposition to the conventional rap discourse-forming values of exceptionalism, chosenness and individualism interpreted within the framework of the Christian anti-values. The research aims at identifying the biblical images, symbols and concepts of Kendrick Lamar's rap texts as the intertextuality devices, which provide the semantic coherence and hypertextuality of the rapper album "Damn". To achieve the purpose, we have applied the methodology incorporating the methods of text interpretation, intertextual and hyper-textual analysis, added by some elements of conceptual and stylistic analysis as well as narrative analysis with the use of the "feedback network" principle. The major findings refer to the identification of the basic devices of biblical intertextuality and their functions in emphasizing the implicit rap-texts meanings, while implying semantic coherence and interrelations between the album compositions. The coherence in the framework of the biblical values bases on allusions, reminiscences, direct and paraphrase quotations from the New and the Old Testament. The basic concepts of the rap texts are explicated either by their keywords and titles denoting the fundamental human sins or virtues or implied by symbolic imagery. Key concepts form a hypo-hyperonymic, metonymic or cause-and-effect relationships with the concept of "Damn" designated by the title of the album. In the framework of the album hypertext, the author-performer applies the narrative principle of "feedback network", which consists in replacement of the first link of the negative feedback loop by a new element an act of kindness that destructs the fatal causal relationship and envolves another scenario in another "possible world".
\end{abstract}

Keywords: biblical intertextuality, rap text, semantic coherence, hyper-text, concept, narrative principle of "feedback network.

Introduction. The relevance of this article is determined by the enormous influence of rap culture, rap ideology and rap aesthetics on the lifestyle and the way of thinking of the multimillion supranational audience of those who "listen" to rap. The phenomenon of rap most seamlessly blends into the philosophy of metamodernism [13], which emerges from postmodernism and reflects the fundamental changes both in the minds of mankind and in the state of culture in the first half of the 21 st century. Metamodernism is not just being "beyond" the boundaries of any paradigm (scientific, artistic, aesthetic, cultural); it is, rather, the freedom from any paradigms and axioms, "the mercurial condition between and beyond irony and sincerity, naivety and knowingness, relativism and truth, optimism and doubt, in pursuit of a plurality of disparate and elusive horizons." [7]. The most accurate concept to convey the very essence of metamodernism may be the term "allacceptance", when, for example, the most complex symbolic or surreal meanings are naturally expressed by a futuristic

(C) N. K. Kravchenko

«International journal of philology» | «Міжнародний філологічний часопис» Vol. 10, № 2, 2019 
underground forms or when an intellectuality and refinement are consistent with epatage, diseuphemization and the maximalism in experimenting with syntax and obscene vocabulary.

Emerging as a genre of metamodernism, rap integrates the marginal individualism with the "openness of being", the latter manifesting itself in a postmodern intertextuality, the richness with allegories, metaphors, symbolic and archetypal imagery paradoxically combined with flamboyant declarations of the most mundane feelings, desires and goals. The barely restored allusive meanings are immediately destroyed by the subsequent context intended to evoke the contradictory meanings, feelings and emotions.

The combination of the inconsistencies marks the texts of the famous African-American rapper Kendrick Lamar [14], who manifests his protest ideology and embodies the rebel architype in a rather unexpected way - by promoting traditional religious values. Rebel puts on a prophet mask: "Salute the truth, when the prophet say" (DNO). However, he still remains a rebel, since the Old Testament framework of his texts conflicts with the ideological and aesthetic paradigm of rap culture and the lifestyle of its adherents ("Sex, money, murder our DNA").

Recent research and publications. The problem of the intersection between religion and rap music is clarified by a number of scholarly works within the musicological and culturological paradigms. First of all, such studies focus on the relationship between rap / hip-hop culture, religion and the issue of racial authenticity and freedom, as well as the religious preferences of individual performers $[11 ; 12]$.

Of particular importance for our research are works which deal with the issue of the intertextuality as a textual and discursive phenomenon, i.e. from the perspective of the sacred scriptures intertextuality [4;9].

Though much work has been done in text linguistics, stylistic and discourseanalysis to explore the intertextuality as a constitutive feature of text, discourse [2; $3]$ and even culture $[5 ; 8 ; 10]$, the problem of the rap discourse intertextual relations from the biblical sources viewpoint remained unsolved.

The purpose of the study is to identify the biblical images and symbols of Kendrick Lamar's rap texts as a means of intertextuality, which provide the semantic coherence and hypertextuality of the album "Damn" [14] while revealing the author-performer meta-modernist opposition to the conventional rap discourse-forming values of exceptionalism, chosenness and individualism interpreted within the framework of the Christian anti-values.

Data and methods. The data analyzed in this paper include the rap texts / compositions from the fourth studio album by American rapper Kendrick Lamar released on April 14, 2017. Investigation has been based on the integrative methodology incorporating the methods of text interpretation, intertextual and hyper-textual analysis, added by some elements of conceptual and stylistic analysis as well as narrative analysis with the use of the "feedback network" principle [1, c. 214-223].

Results. The lyrics of the album reflects the struggle between vanity and humility, sex and love, revenge and forgiveness, virtue and sin ("But is America honest or do we bask in sin?"). The rapper does not hide that he needs others to pray for him: "the whole world wants me to pray for 'em / but is no one praying for me" ("Feel").

Album compositions form the hypertext, whose value and semantic coherence is provided by allusions, reminiscences, direct and paraphrase 
quotations from the New and the Old Testament. The titles of most texts denote the basic human sins or virtues: "Loyalty", "Love", "Humble", "Pride", "Lust", "Fear", etc. [14].

The basic concepts of the texts, either explicated by the titles and keywords, or implied by symbolic imagery, constitute a hypo-hyperonymic, metonymic or cause-and-effect relationships with the concept of "Damn" designated by the title of the album.

The key concept of the album is "Fear", which is interpreted by the artist from different facets. On the one hand, the feeling of fear is perceived as a punishment («he's gonna punish us for our iniquities, for our disobedience») and recompense for sins, in particular for pride: «pride's gonna be the death of you and you and me»" ("Pride"); "I'm talkin' fear, fear of losin' loyalty from pride, I'm talkin' fear, fear that my humbleness is gone") and the loss of love: "I'm talkin' fear, fear that love ain't livin' here no more" ("Fear").

The fear borders with the feeling of fatality since the "lyric hero" is doomed to fear due to his genetically innate sinfulness (composition "DNA": "I got dark, I got evil, that rot inside my DNA"). The feeling of fatality coordinates "DNA" with the composition "Blood", where the hero is killed by a blind woman (the personification of fate) because he is doomed to die for his unrighteous life: "Oh yes, you have lost something. You've lost your life!".

Fear as a punishment that cannot be avoided is internalized by the authorperformer (a) at the personal level (in different periods of his life, the fear remains his permanent "companion" only changing its facets, illustrated by three rap narratives of the rapper's childhood, adolescence and maturity: "When I was 27, I grew accustomed to more fear Accumulated 10 times over throughout the years") as well as (b) in the racial
("But you have to understand this, man, that we are a cursed people") and (c) planetary dimensions: "Fear, what happens on Earth stays on Earth"; "Earth is no more, why don't you burn this muh'fucka?".

Attributes of the fear include selfloathing (the composition "Feel"), suffering, pain, despair and depression: "Why God, why God do I gotta suffer? Pain in my heart carry burdens full of struggle. Why God, why God do I gotta bleed?"; "I do not think I could find a way to make it on this earth" ("Fear").

The motive of "fear" reaches is logical conclusion in the composition "Blood", in which the rapper accepts and "experience" one of his main fears - the fear of death. The story events do not obey the "common sense" logic. They rather resemble a fairy tale narrative with symbolic subtext and elements of mythologization, i.e. the mythological motive of fate, associated with the images of Atropos (one of the goddesses of fate, cutting the thread of life), and Tyche - the goddess of Chance and Fate, usually symbolized by a blind girl. At the same time, this rap narrative somehow reminds a psychotherapeutic technique, when the hero has to go through his fears to be free from them.

Rhetorical questions "Is it wickedness? Is it weakness?" which open the narrative do not explicitly relate to its meaning being rather subordinate to the concept-idea of the album hypertext. "Is it wickedness? Is it a weakness?" actually means "Is this (what has happened) a punishment for sins or for the weakness not to admit one's sins and repent of them? Moreover, the choice of life or death also depends on the answer to these questions: "Are we gonna live or die?"

In such a way, the concept of fear is internalized by the author-performer in the framework of the Christian tradition: as "the fear of God", of committing sin 
and thus losing the love of the Lord. This key conceptual motive is expressed both explicitly ("Until we come back to these laws, statutes and commandments, and do what the Lord said, these curses are gonna be upon us") and implicitly: through allusions to the trials of Job ("Is it for the moment, and will he see me as Job? Take it from me and leave me worse than I was before?") and the direct quote from the Deuteronomy ("Deuteronomy 28:28 says, "The Lord shall smite thee with madness, and blindness, and astonishment of heart".),

Freedom from Fear is equated then with Freedom from Sin ("There is no fear in love. But perfect love drives out fear" (1 John 4:18 New International Version [6]).

The destruction of karmic doom is possible only through love (compare with a similarly-named track "Love") and goodness. Good acts trigger the narrative principle of "feedback network", involving the fate of several generations. To change the inherited doom, it is necessary to destroy the fatal causal relationship, returning to the first "evil" link and replacing it by a kindness.

The principle of feedback loop is illustrated by the rap composition "Duckworth", an autobiographical parable in which Kendrick shows how his father's good deed restored a disturbed balance and destroyed the karmic doom ("one decision changed both of they lives"). The robbery at a local KFC where Kendrick's father, Ducky, was working could have resulted in Ducky's death. However, a member of the Mafia named Anthony spared Ducky's life for the latter's generosity:

"Free chicken every time Anthony posted in line

Two extra biscuits, Anthony liked him and then let him slide

They didn't kill him; in fact, it look like they're the last to survive".
Kindness was returned twofold: if his father had been killed, Kendrick would not have been born. Thanks to his father's act, Kendrick, like a matrix hero, dodged a bullet once aimed at his father (this image is found in another album composition DNA" and metaphorically associate death with unbirth).

Conclusions and discussion. The major finding is that the biblical intertextuality of the Kendrick Lamar's album "Damn" triggers the implicit meanings, integrating the album compositions into coherent semantic whole based on allusions, reminiscences, direct and paraphrase quotations from the New and the Old Testament. The basic concepts of the rap texts, explicated by the keywords and titles or implied by symbolic images, constitute a hypohyperonymic, metonymic or cause-andeffect relationships with the concept of "Damn" denoted by the album title. The narrative principle of "feedback network", applied by the rapper, consists in replacement of the first link of the negative feedback loop by a new element that destroys the fatal causal relationship and envolves another scenario of the rapper's life.

As a whole, the study of biblical intertextuality identified in the rap texts sheds more light on the problem of implicit meanings and cultural symbols of the contemporary rap lyrics.

\section{Список використаних джерел}

1. Жихарєва О. О. Екопоетика англомовного біблійного дискурсу: концепти, образи, нарації : монографрія. Київ : КНЛУ, 2018. 312 с.

2. Кравченко Н. К. Дискурс и дискурс-анализ: краткая энциклопедия. Киев : «Интерсервис», 2017. 288 с.

3. Кравченко Н. К. Практическая дискурсология: школы, методы, методики современного дискурсанализ: практическое пособие. Луцк : «Волиньполіграфр», 2012. 251 с. 
4. Aichele G \& Walsh R. Screening Scripture: Intertextual Connections between Scripture and Film. Harrisburg: Trinity Press International, 2002. 336 p.

5. Allen G. Intertextuality. New Critical Idiom. $2^{\text {nd }}$ edition. London, New York : Routledge, 2011.244 p.

6. Book of 1 John. URL : https://www.biblestudytools.com/1-john/

7. Cliff A. Popping Off: How Weird Al, Drake, PC Music and You Are All Caught up in the Same Feedback Loop. The Fader, 8 August 2014.

8. Genette G. Palimpsests: literature in the second degree / transl. Ch. Newman, C. Doubinsky. - Lincoln, NE : University of Nebraska Press, 1997. $490 \mathrm{p}$.

9. Moyise S. Intertextuality and the study of the Old Testament in the New Testament. The Old Testament in the New Testament. Sheffield: Sheffield Academic Press, 2000. Pp. 14-41.

10. Orr M. Intertextuality: Debates and Contexts. Cambridge : Polity Press, 2003. $256 \mathrm{p}$.

11. Pyon, K. Towards an AfricanAmerican Genealogy of Market and Religion in Rap Music. Popular Music and Society. 2019. Vol. 42 (3). Pp. 363-384.

12. Sorett J. 'Believe me, this pimp game is very religious': Toward a religious history of hip hop. Culture and Religion. 2009. Vol. 10 (1). Pp. 11-22.

13. Van den Akker, Robin, Alison, Gibbons \& Vermeulen, Timotheus. Metamodernism: Historicity, Affect, and Depth after Postmodernism (Radical Cultural Studies). London; New York : Rowman \& Littlefield International. 2017. $260 \mathrm{p}$.

14. Kendrick Lamar. Damn (Full Album). URL: You Tube https://www.google.com/search

\section{References}

1. Aichele, G \& Walsh, $R$ (2002). Screening Scripture: Intertextual
Connections between Scripture and Film. Harrisburg: Trinity Press International.

2. Allen, G, (2011). Intertextuality. New Critical Idiom. $2^{\text {nd }}$ edition. London, New York: Routledge.

3. Book of 1 John. URL https://www.biblestudytools.com/1-john/

4. Cliff, A. (2014). Popping Off: How Weird Al, Drake, PC Music and You Are All Caught up in the Same Feedback Loop. The Fader, 8 August 2014.

5. Genette G. (1997). Palimpsests: literature in the second degree / transl. Ch. Newman, C. Doubinsky. Lincoln, NE : University of Nebraska Press.

6. Kravchenko N. K. (2017). Dyskurs y dyskurs-analyz: kratkaia entsyklopedyia. Kyev: Interservys.

7. Kravchenko N. K. (2012). Praktycheskaja diskursologija: shkoly, metody I metodiki sovremennoho diskursanalisa: praktycheskoje posobije. Lutsk: Volyn'poligraf.

8. Moyise, S (2000). Intertextuality and the study of the Old Testament in the New Testament, in: S Moyise, (ed), The Old Testament in the New Testament. Sheffield: Sheffield Academic Press, 1441.

9. Orr, Mary. (2003). Intertextuality: Debates and Contexts. Cambridge: Polity Press.

10. Pyon, K. (2019). Towards an African-American Genealogy of Market and Religion in Rap Music. Popular Music and Society (Vol. 42 (3), pp. 363-384).

11. Sorett J. (2009). 'Believe me, this pimp game is very religious': Toward a religious history of hip hop. Culture and Religion (Vol. 10 (1), pp. 11-22).

12. Van den Akker, Robin, Alison, Gibbons \& Vermeulen, Timotheus (2017). Metamodernism: Historicity, Affect, and Depth after Postmodernism (Radical Cultural Studies). London; New York: Rowman \& Littlefield International.

13. Zhihareva, O. (2018). Ekopoetyka anglomovnoho religijnoho dyskursu: 
kontsepty, obrazy, naratsyji : monografija. Kyev: KNLU.
14. Kendrick Lamar. Damn (Full Album). URL : You Tube https://www.google.com/search

\section{ЗАСОБИ БІБЛІЙНОӤ ІНТЕРТЕКСТУАЛЬНОСТІ В ТЕКСТАХ АФРОАМЕРИКАНСЬКОГО РЕПУ (НА МАТЕРІАЛІ АЛЬБОМУ КЕНДРИКА ЛАМАРА "DАMN")}

\section{Н. К. Кравченко}

Анотація. Стаття присвячена вивченню біблійної інтертекстуальності альбому Кендріка Ламара "Damn", що відображає реперську метамодерністську опозицію до традиційних дискурсотвірних цінностей реп-культури, а саме винятковості, обраності та індивідуалізму, інтерпретованих в рамках християнських анти-цінностей. Дослідження має на меті визначення біблійних образів, символів та концептів реп-текстів Кендріка Ламара як засобів інтертекстуальності, що забезпечують смислову когерентність та гіпертекстуальність композицій альбому “Damn”. Для досягнення мети застосована методика, що включає методи інтерпретації тексту, інтертекстуального та гіпертекстуального аналізу, із залученням елементів кониептуального та стилістичного аналізу, а також наративного аналізу 3 використанням наративного принципу “петлі зворотного зв'язку". Основні висновки стосуються ідентифрікації засобів біблійної інтертекстуальності та ії функцій у маркуванні імліцитних смислів реп-текстів, їхньої взаємоузгодженості $i$ когерентності у фоорматі всього альбому. Когерентність базується на біблійних цінностях, що актуалізуються алюзіями, ремінісценціями, прямими $i$ перефрастичними цитатами з Нового та Старого Завіту. Основні концепти рептекстів експлікуються ключовими словами та заголовками, що позначають основні людські гріхи чи чесноти, або імлікуються символічною образністю. Ключові концепти утворюють гіпо-еіперонімічний, метонімічний або причиннонаслідковий зв'язок із кониептом “Damn”, позначеним назвою альбому. В рамках гіпертексту альбому автор-виконавець застосовує наративний принцип "петлі зворотного зв'язку", який полягає в заміні першої ланки петлі на новий елемент, що руйнує фратальний причинно-наслідковий зв'язок $і$ включає інший сценарій $в$ іншому "можливому світі".

Ключові слова: біблійна інтертекстуальність, реп-текст, семантична когерентність, гіпертекст, концепт, наративний принцип "петлі зворотного зв'язку. 